\title{
DEFICIENCIES IN THE OLD BUILDINGS OF THE EDUCATIONAL INSTITUTIONS IN THE DISTRICT OF COMAS
}

Edgar Enrique Aroni Geldres

Federico Villarreal National University EUPG-UNFV, Lima, (Peru).

E-mail: 2020005075@unfv.edu.pe

ORCID: https://orcid.org/0000-0001-7928-3637

Doris Esenarro

Federico Villarreal National University EUPG-UNFV, Lima, (Peru).

E-mail: desenarro@unfv.edu.pe

ORCID: https://orcid.org/0000-0002-7186-9614

Karina Hinojosa

Federico Villarreal National University-UNFV, Lima, (Peru).

E-mail:khinojosa@unfv.edu.pe

ORCID: https://orcid.org/0000-0003-1237-9110

Nelly Mendez Gutierrez

Federico Villarreal National University-UNFV, Lima, (Peru).

E-mail:nmendez@unfvedu.pe

ORCID: https://orcid.org/0000-0001-5524-6081

Recepción: 26/02/2021 Aceptación: 02/04/2021 Publicación: 07/05/2021

\section{Citación sugerida:}

Aroni, E. E., Esenarro, D., Hinojosa, K., y Mendez, N. (2021). Deficiencies in the old buildings of the educational institutions in the district of Comas. $3 C$ Tecnología. Glosas de innovación aplicadas a la pyme, Edición Especial, (mayo 2021), 163-175. https://doi.org/10.17993/3ctecno.2021.specialissue7.163-175 


\section{ABSTRACT}

The present research aims to analyze the deficiencies in the old buildings of the educational institutions of the Comas district; the government has put its interest in reducing the gap in the educational infrastructure in a complementary way in which preventive and corrective maintenance actions are carried out, while school construction follows a cumbersome path. This delays the investment required in schools and universities. The methodology is based on the percentage variations of the schools by levels; for this, a sample of educational institutions was considered, based on critical components such as basic infrastructure, essential services, and advanced infrastructure, deficiencies in basic infrastructure were analyzed, verifying that this is a significant indicator that heralds quality and safety. Hence, it is crucial to work on the replacement of educational infrastructure. The results showed that, in the period 2017-2020, the percentage variation was 7.5\% for initial education; meanwhile, for primary education, it was $3.61 \%$, and for secondary education, the percentage variation was $7.14 \%$.

\section{KEYWORDS}

Deficiencies, Old buildings, Basic infrastructure, Essential services, Advanced infrastructure. 


\section{INTRODUCTION}

A significant step forward in improving educational infrastructure in Peru was the approval of the National Educational Infrastructure Plan (PNIE) to 2025 (Minedu, 2017). As a result, a series of educational infrastructure works have been carried out nationwide, in line with the identification of the problem established by the National Educational Infrastructure Census (execution period: October 2013 - March 2014), i.e., the imperative need for reinforcement and rehabilitation of educational infrastructure $(51.0 \%)$ and replacement of infrastructure (demolition) (25.0\%), and, to a lesser extent, maintenance (non-structural) $(15.0 \%)$. Only $9 \%$ of the educational institutions did not require intervention (Ministry of Education, 2014). The data are alarming and give an x-ray of the state in which educational institutions operate, contravening physical quality precepts as a basic aspect of the quality of education (Parasuraman, Zeithaml \& Berry, 1985).

In this framework, the PNIE to 2025 has two critical columns on which public investment is destined; the first refers to the existing infrastructure gap and the second one to the additional investment needs (Minedu, 2019). Although the efforts to reduce the current educational infrastructure gap are laudable, in the geographic area of UGEL 04, especially in the district of Comas, there are deficiencies in the old constructions of educational institutions, which implies the need to improve the aesthetic quality and infrastructure conditions of academic environments.

Population growth in Metropolitan Lima has meant the emergence of new housing spaces in the city. In northern Lima, one of the districts that grew was Comas. Human settlements sprang up, and their inhabitants needed schools and colleges. This action implied the construction of educational infrastructure. However, this brought two further problems. The first one referred to the physical and legal clearing of the land occupied by the educational premises and the empirical criteria used in the construction of classrooms without adequate planning. A significant advance to this problem was the Guide for the Design of Educational Spaces (Ministry of Education, 2015).

Although the state has put its interest in reducing the educational infrastructure gap, they complementarily perform preventive and corrective maintenance actions. At the same 
time, the construction of schools follows a cumbersome path. This delays the investment required in schools and colleges.

The study's objective was to analyze the deficiencies in the old constructions of educational institutions in the district of Comas, based on the percentage variations in the period 2017-2020; likewise, for the specific objectives: basic infrastructure, essential services, and advanced infrastructure.

\section{METHOD}

A quantitative study was carried out using historical information, which implied going back in time by observing events that had taken place previously. Hence, it corresponds to a retrospective study (Alto, Lopez \& Benavente, 2013) with a non-experimental design at a descriptive level (Hernandez, Fernandez \& Baptista, 2014).

Likewise, the study population consisted of 97 public educational institutions built in the Comas district, corresponding to the Regular Basic Education levels. Of this population, $50.5 \%$ were at the pre-school level, $32.0 \%$ at the primary level, and $17.5 \%$ at the secondary level (Sanchez \& Reyes, 2015).

Thus, the selected sample was non-probabilistic by convenience because it focused only on educational institutions with old buildings (25 years or more) in the district of Comas, using the criteria of the current state of walls, roofs, and floors, obtaining a sample of 79 educational institutions. Additionally, content analysis and documentary analysis were considered.

In order to evaluate the deficiencies in the old constructions of the educational institutions in the district of Comas, the defects were quantified by means of reports extrapolated from the office of educational infrastructure, based on a card in which three dimensions were considered: basic infrastructure, essential services and infrastructure described by 15 indicators. The card was subjected to KR 20 reliability, obtaining a coefficient of 0.720 higher than the established 0.700 .

As for the procedure, a historical sequence was elaborated between the years 2017 and 2020 inclusive. The data were analyzed descriptively using the Excel tool. 


\section{RESULTS}

Below are the results obtained from the studied variable old constructions of educational institutions, described from its components: basic infrastructure, essential services, and advanced infrastructure:

As presented in Table 1, the percentage values refer to the proportion of colleges and schools that constitute old constructions, finding for the period 2017-2018, a percentage variation of $2.50 \%$, corresponding to the initial education level; likewise, another variation of $2.41 \%$ was found at the primary level, finally, the finding of a variation of $2.38 \%$ that corresponded to the secondary level (Ministry of Education, 2020).

Concerning the 2018-2019 period, a percentage variation of $2.43 \%$ was found for the initial education level, while for the primary education level, it was $-1.18 \%$; on the other hand, in the secondary education level, the variation was $2.33 \%$.

On the other hand, regarding the $2019-2020$ period, a percentage variation of $2.38 \%$ was found for the initial education level. The percentage variation was $2.38 \%$, and, at the secondary education level, it was $2.2 \%$.

Finally, in the period 2017-2020, the percentage variation was $7.5 \%$ for initial education; while, for primary education, this was $3.61 \%$ and, for secondary education, the percentage variation was $7.14 \%$.

Table 1. Percentage of deficiencies in old buildings, by levels of regular basic education.

Source: own elaboration.

\section{EBR levels}

Initial

Elementary

Secondary
Old buildings

2018

$82 \%$

$85 \%$

$86 \%$
2019

$84 \%$

$84 \%$

$88 \%$
2020

$86 \%$ $86 \%$ $90 \%$

Concerning the essential infrastructure component with its indicators for walls, roofs, and floors, the following results were obtained:

Table 2. Percentage of the basic infrastructure of old buildings by levels of regular primary education.

\section{EBR levels}

Initial
2017

$85 \%$
Old buildings

2018

$87 \%$
2019

$88 \%$
2020

$89 \%$ 


\begin{tabular}{|l|l|l|l|l|l|}
\hline Elementary & $86 \%$ & $88 \%$ & $89 \%$ & $91 \%$ \\
\hline Secondary & $87 \%$ & $88 \%$ & $90 \%$ & $92 \%$ \\
\hline
\end{tabular}

Source: own elaboration.

In Table 2, the percentage values refer to the proportion of schools and schools, regarding walls, roofs, and floors, finding for the period 2017-2018, a percentage variation of 2.35\%, corresponding to the initial education level; in the same way, another variation of $2.33 \%$ was found in the primary level, finally, the finding of a variation of $1.15 \%$ that corresponded to the secondary level (Campana et al., 2014).

In the 2018-2019 period, the percentage variation obtained was $1.15 \%$ for initial education, while for the primary education level, it was $1.14 \%$, and the percentage variation for the secondary education level was $2.27 \%$.

In the 2019-2020 period, the percentage variation achieved was $1.14 \%$ at the initial education level. Meanwhile, the percentage variation was $2.25 \%$ for the primary education level and, for the secondary education level, the percentage variation was $2.22 \%$ for secondary education level.

Finally, to point out that the percentage variation for the period $2017-2020$ was $4.71 \%$ for initial education, while for primary education, it was $5.81 \%$. Finally, for the primary education level, the percentage value was $5.75 \%$.

The following results were obtained for the essential building services component, composed of the indicators electricity, water, drainage, good toilets, and bad toilets:

Table 3. Percentage of essential services of old constructions, by levels of regular primary education.

Source: own elaboration.

\begin{tabular}{|c|c|c|c|c|}
\hline EBR levels & \multicolumn{4}{|c|}{ Old buildings } \\
& $\mathbf{2 0 1 7}$ & $\mathbf{2 0 1 8}$ & $\mathbf{2 0 1 9}$ & $\mathbf{2 0 2 0}$ \\
\hline Initial & $82 \%$ & $86 \%$ & $89 \%$ & $90 \%$ \\
\hline Elementary & $84 \%$ & $87 \%$ & $90 \%$ & $91 \%$ \\
\hline Secondary & $86 \%$ & $88 \%$ & $92 \%$ & $93 \%$ \\
\hline
\end{tabular}

In Table 3, the percentage values allude to the proportion of schools and colleges, regarding electricity, water, drainage, good toilets, and bad toilets, finding for the period 2017-2018, a percentage variation of $2.38 \%$, corresponding to the initial education level; in the same 
way, another variation of $3.57 \%$ was found in the primary level, finally, the finding of a variation of $2.33 \%$ that corresponded to the secondary level (Palacio, 2018).

In the 2018-2019 period, the percentage variation obtained was 3.45\% for initial education, while for the primary education level, it was 3.33\%, and the percentage variation for the secondary education level was $4.55 \%$.

In the 2019-2020 period, the percentage variation achieved was $1.12 \%$ at the initial education level. Meanwhile, the percentage variation was $1.11 \%$ for the primary education level and, for the secondary education level, the percentage variation was $1.09 \%$ for secondary education level.

Finally, to point out that the percentage variation for the period 2017-2020 was 9.56\% for initial education, while for primary education, it was 8.33\%. Finally, for the primary education level, the percentage value was $8.14 \%$.

Concerning the advanced infrastructure component composed of its indicators library, laboratory, workshops, teachers, administrative, computer and internet, the following result was obtained:

Table 4. Percentage of the advanced infrastructure of old buildings by the level of regular primary education.

\section{Source: own elaboration.}

EBR levels

Initial

Elementary

Secondary

\section{7}

$72 \%$

$78 \%$

$80 \%$

\section{Old buildings} 2018

$74 \%$

$80 \%$ $82 \%$
2019

$76 \%$

$82 \%$ $84 \%$
2020

$78 \%$

$84 \%$ $86 \%$

In Table 4, the percentage values allude to the proportion of colleges and schools, regarding library, laboratory, workshops, teachers, administrative, computer and internet, finding for the period 2017-2018, a percentage variation of $2.78 \%$, corresponding to the initial education level; in the same way, another variation of $2.56 \%$ was found in the primary level, finally, the finding of a variation of $2.50 \%$ that corresponded to the secondary level.

In the 2018-2019 period, the percentage variation obtained was 2.70\% for initial education, while for the primary education level, it was $2.50 \%$, and the percentage variation for the secondary education level was $2.44 \%$. 
In the 2019-2020 period, the percentage variation achieved was $2.63 \%$ at the initial education level. Meanwhile, the percentage variation was $2.44 \%$ for the primary education level and, for the secondary education level, the percentage variation was $2.38 \%$.

Finally, to point out that the percentage variation for the period 2017-2020 was $8.33 \%$ for initial education, while for primary education, it was $7.50 \%$. Finally, for the primary education level, the percentage value was $7.50 \%$.

The objective of the study was to analyze the deficiencies in the old constructions of the educational institutions of the district of Comas, based on the percentage variations in the period 2017-2020; for this purpose, a sample of educational institutions was considered, based on critical components such as basic infrastructure, essential services, and advanced infrastructure.

\section{DISCUSSION}

These components have been considered by the Ministry of Education, based on the PNIE 2025, which has become a tool to implement the educational infrastructure policy; however, the infrastructure gap has been increasing year by year as a result of population growth and the lack of capacity to channel state resources and direct it to the investment of infrastructure projects, constituting a substantial problem faced by educational institutions in the jurisdiction of Comas. Although the efforts of the governing bodies are monumental, as, in the case of the allocation of 50 million soles for the construction of 5 schools, it is insufficient, it barely represents $6.32 \%$ of the 79 schools that require infrastructure replacement; this means that at an average rate of 5 schools per year in 10 years the horizon of 50 schools will be covered. This is a stark reality, considering the increase in the school population year by year. The results found are in line (Campana et al., 2014) when they argue that what governments have done is to focus on strengthening flagship schools, but they have not concentrated on closing infrastructure gaps. They found a sustained increase in the levels of public investment in education, but without any positive impact; on the contrary, he notes the increase in the infrastructure gap.

The first specific objective, which focused on analyzing the deficiencies in old buildings' basic infrastructure, confirms that educational institutions have been gradually confirming 
year by year the deterioration of their basic infrastructure. So this finding is similar when he verified that an educational institution in Chorrillos was on the verge of collapse (Palacios, 2018). Gradually, the classrooms have been succumbing to the passage of time and putting schoolchildren's lives at risk. These results corroborate, on the other hand, the deterioration of the physical quality, that is, the perceptions that parents have about the educational institution where their children study, finding it to be adverse. This reality is located in the district of Comas, and that is why the improvement of the educational service is required, as Rodrigo (2019) argues when addressing the progress of the academic service through the design of the infrastructure, in this case, of primary and secondary education, emphasizing quality and safety.

The second specific objective focused on analyzing the essential services in the basic infrastructure of old buildings: electricity, water, drainage, full toilets, and excellent or bad toilets. The result reveals percentage variations that remain stationary over time but show severe limitations in essential services, especially water and drainage. This reality's harshness only further deteriorates the quality of life of schoolchildren, thus affecting their right to quality education. Education is an essential asset in people's lives because, in the long term, it guarantees quality professionals; therefore, attention must be paid to educational infrastructure because there is a significant relationship between educational infrastructure and student performance.

The third specific objective focused on advanced infrastructure, based on indicators such as a library, laboratory, workshops, teachers, administrative, computer, and internet. The result found for this component also confirms the percentage variations to the detriment of a better educational and human development of schoolchildren. Therefore, this line of denials ensures the existing weaknesses in educational infrastructure, which extends to the area of human development, the undermining of the right to education, and a growing deterioration of academic quality, which goes hand in hand with educational infrastructure. For this reason, the PNIE to 2025 will have a basis if the advanced infrastructure is improved, as a result of viable strategic actions that ensure the primary conditions of safety and functionality in the existing educational infrastructure. 


\section{CONCLUSIONS}

The deficiencies in the old constructions of the educational institutions of the district of Comas were analyzed, whose reflection is the percentage variations found between 2017-2020, reveal that maintenance does not mitigate or strengthen the educational infrastructure, but are palliatives that are worsening over time pressured by the academic coverage.

Deficiencies in basic infrastructure were analyzed, confirming that this is a significant indicator that foreshadows the quality and safety that both parents and students need to have a quality education, so it is essential to replace educational infrastructure.

Deficiencies in essential services were analyzed, confirming that this is a significant indicator that must be addressed if we seek to promote the right to quality education.

Deficiencies in advanced infrastructure were analyzed, confirming that this is a significant indicator that must be addressed if the right to quality education is promoted.

The limitations of the study may lie in the instrument designed to collect data from the structured reports in the area of Educational Infrastructure, so it is suggested that a robust mechanism be designed to measure in its actual dimension the level of educational infrastructure, carrying out a pilot study that includes several educational institutions in Metropolitan Lima, to validate it later and serve as a reference to collect data for fieldwork.

As a future perspective, it would be essential to focus on recently built schools to determine, through a longitudinal study with other educational institutions that only benefit from maintenance items, the effect of the perceptions produced by the design of an educational infrastructure academic performance of students.

\section{REFERENCES}

Ato, M., López, J., \& Benavente, A. (2013). Un sistema de clasificación de los diseños de investigación en psicología. Anales de psicología, 29(3), 1038-1059. http://dx.doi. org/10.6018/analesps.29.3.178511 
Campana, Y., Velasco, D., Aguirre, J., \& Guerrero, E. (2014). Inversión e infraestructura educativa: una aproximación a la medición de sus impactos a partir de la experiencia de los colegios emblemáticos. Informe final. Consorcio de Investigación Económica y Social.

Hernández, R., Fernández, C., \& Baptista, P. (2014). Metodología de la investigación (6. ${ }^{\text {a }}$ ed.). McGraw Hill Educación.

Ministerio de Educación. (2014). Censo Nacional de Infraestructura Educativa. MINEDU/ INEI.

Ministerio de Educación. (2015). Guía de diseños de espacios educativos. MINEDU. http:// www.minedu.gob.pe/p/pdf/guia-ebr-jec-2015.pdf

Ministerio de Educación. (2020). Estadística online 2020, UGEL 04. Escale.

Palacios, J. B. (2018). La inversión pública en educación y la brecha en infraestructura fisica en la educación básica regular durante el período 2000-2015 (Tesis de Maestría en gobierno y gestión pública). Universidad San Martin de Porres. https://repositorio.usmp.edu. pe/handle/20.500.12727/3273?show=full

Parasuraman, A., Zeithaml, V., \& Berry, L. (1985). A Conceptual Model of Service Quality and its Implications for Future Research. Journal of Marketing, 49(4), 41-50. https: / / www.jstor.org/stable / 1251430? origin=crossref\&seq=1

Ramón, S. (2020). Infraestructura educativa y el rendimiento académico de estudiantes de segundo grado de secundaria en el Perú en el año 2018 (Tesis de Pregrado). Pontificia Universidad Católica del Perú. http://tesis.pucp.edu.pe/repositorio/bitstream/ handle/20.500.12404/16873/RAM\%c3\%93N_HUAM\%c3\%81N_SANDRA_ MARIELLA_Infraestructura $\% 20$ educativa.pdf? sequence= $1 \&$ isAllowed $=\mathrm{y}$

Resolución Ministerial No 153-2017- MINEDU. (2017, 6 de marzo). En Normas legales, No 13992. Diario Oficial "El Peruano". Ministerio de Educación.

Resolución Ministerial No 621-2019- MINEDU. (2019, 27 de diciembre). En Normas legales, $\mathcal{N}^{\circ}$ 15209. Diario Oficial "El Peruano". Ministerio de Educación. 
Rodrigo, S. (2019). Mejoramiento del servicio educativo mediante el diseño de la infraestructura primaria Nº10254 Santa Clara, Ferreñafe-2018 (Tesis de Pregrado). Universidad César Vallejo. http://repositorio.ucv.edu.pe/bitstream/handle/20.500.12692/46291/Rodrigo_ VSYSD.pdf?sequence $=1$ \&isAllowed $=y$

Sánchez, H., \& Reyes, G. (2015). Metodología y diseños en la investigación científica (5. ${ }^{a}$ ed.). Business Support Aneth. 
